\title{
Proteção contra infecções pelo BHV-5 induzida por uma vacina para BHV-1 e por uma amostra recombinante de BHV-5*
}

\author{
ALESSANDRA D'AVILA DA SILVA
}

Paulo Michel Roehe (Orientador - UFRGS)

Ana Cláudia Franco (Co-orientadora - UFPel)

Banca: Amauri Simonetti (UFRGS), Cláudio Wageck Canal (UFRGS), Luciane Teresinha Lovato (UFSM)

O herpesvírus bovino tipo 5 (BHV-5) é responsável por meningoencefalites necrosantes em bovinos, com prevalência aparentemente mais significativa nos países do hemisfério sul, principalmente Brasil e Argentina. Objetivando um melhor entendimento sobre aspectos de proteção cruzada induzida através da utilização de vacinas contra BHV-1 frente a infecções por BHV5, o presente estudo envolveu a imunização de coelhos e bovinos com uma vacina recombinante de BHV-1 e subseqüente desafio com uma amostra altamente virulenta de BHV-5. Após o desafio, 2 de 5 coelhos previamente vacinados morreram apresentado sinais neurológicos de meningoencefalite, bem como 3 de 5 coelhos do grupo de animais não vacinados. Quando este experimento foi realizado em bovinos, animais do grupo vacinado desenvolveram sinais brandos de comprometimento nervoso e doença respiratória. No grupo de animais não vacinados, contudo, 2 animais morreram nos dias 7 e 11 pós desafio. No dia 21 pós desafio, 4 de 8 bovinos vacinados e 2 bovinos não vacinados foram sacrificados e apresentaram lesões típicas de BHV-5 no encéfalo. No dia 60 pós desafio, os bovinos remanescentes foram submetidos à administração de dexametasona visando a reativação do vírus. Após a reativação, não foram evidenciados sinais de comprometimento nervoso ou respiratório em ambos os grupos. Contudo, lesões atróficas no encéfalo estavam presentes em 3 animais vacinados bem com em 2 bovinos não vacinados. Conclui-se que a imunização com esta vacina de BHV-1 conferiu proteção parcial a coelhos e bovinos posteriormente desafiados com BHV-5. Como segunda parte deste trabalho, na busca de uma amostra atenuada com potencial para ser utilizada como imunógeno, uma amostra de BHV-5 recombinante com deleções nos genes gI, gEe US9 foi avaliada quanto a seu potencial patogênico, imunogênico e capacidade de reativação utilizando coelhos com idades variando entre 4 e 8 semanas como modelo experimental. Nos coelhos de 4 semanas de idade, o mutante causou doença levando à morte 4 de 13 animais (30,7\%) enquanto que a amostra de vírus selvagem levou à morte 11 de13 animais (84,6\%). Após o desafio, coelhos previamente vacinados não desenvolveram sinais clínicos compatíveis com infecções por BHV-5 e apresentaram anticorpos específicos para BHV-5. Em coelhos de 8 semanas de idade, o mutante não induziu sinais da doença durante a fase aguda da infecção, enquanto a amostra de vírus selvagem foi fatal para 5 de $9(55,5 \%)$ animais. Após administração de dexametasona, animais inoculados com o vírus recombinante não apresentaram sinais neurológicos nem eliminaram vírus nas secreções nasais, enquanto que no grupo inoculado com o vírus parental houve eliminação de vírus através das secreções nasais durante 10 dias em 100\% dos animais. Estes resultados sugerem que o mutante de BHV-5 foi parcialmente atenuado quando testado em coelhos de 4 semanas de idade sendo que animais previamente imunizados com tal recombinante ficaram protegidos frente ao desafio com a amostra parental. Estudos posteriores na espécie alvo serão necessários para avaliar as propriedades patogênicas e imunogênicas do vírus recombinante visando sua utilização como uma vacina atenuada diferencial para bovinos.

Descritores: BHV-1, BHV-5, vacina recombinante, coelho, bovino. 


\title{
Protection against infections by BHV-5 induced by a vaccine for BHV-1 and by a recombinant strain of BHV-5*
}

\author{
ALESSANDRA D'AVILA DA SILVA
}

Paulo Michel Roehe (Adviser - UFRGS)

Ana Cláudia Franco (Co-Adviser - UFPel)

Committee: Amauri Simonetti (UFRGS), Cláudio Wageck Canal (UFRGS), Luciane Teresinha Lovato (UFSM)

Bovine herpesvirus type $5(\mathrm{BHV}-5)$ is responsible for a necrotizing meningoencephalitis in cattle, whose prevalence is apparently higher in southern hemisphere countries, particularly Brazil and Argentina. Aiming a better understanding about aspects of the induced cross protection between BHV-1 vaccines to BHV-5 infections, the present study involved vaccination of rabbits and calves with a recombinant vaccine of BHV-1 and subsequent challenge with a highly virulent BHV-5 strain. After challenge, 2 out of 5 rabbits previously vaccinated died displaying neurological signs of meningoencephalitis, as did 3 out of 5 unvaccinated rabbits. When this experiment was realized in calves, animals of vaccinated group developed mild signs of neurological compromise and respiratory disease. In the unvaccinated group, however, 2 animals died at days 7 and 11 post challenge. At day 21 post-challenge, 4 out of 8 calves vaccinated and 2 unvaccinated groups were culled and had typicals BHV-5 lesions in brain tissues. In the day 60 post challenge, animals remanescentes were submitted the treatment of dexametasone. However, after reactivation, no respiratory or neurological signs were noticed. Atrophic brain lesions, however were present in three of the vaccinated as well as in two unvaccinated calves. It is concluded that, immunization with this BHV-1 vaccine confer partial protection to rabbits or calves when challenged with BHV-5. As a second part this work, in search for an attenuated strain that could potential to be used as an immunogen, a recombinant with a deletion in the gI, gE, US9 genes, was evaluated the pathogenicity, immunogenicity and reactivation using four and eight week old rabbits as models. In four weeks old rabbits, the mutant caused disease leading to death in 4/13 (30.7\%), whereas the wild type virus culled 11/13 (84.6\%) of the animals. After challenge, vaccinated previously rabbits did not develop clinical signs of the disease and developed BHV-5 specific antibodies. In the eight week old rabbits, the mutant did not induce signs of the disease during acute infection, whereas the wild type virus was fatal for 5/9 (55.5\%) of the animals. After Dx adminitrationt animals inoculated with recombinant virus not showed any neurological signs neither eliminated virus in nasal secretion while the group inoculated with the parental virus was eliminated during 10 days in $100 \%$ of animals. These results suggested that the BHV-5 deletion mutant was partially attenuated for rabbits. And animals previously vaccinated with recombinant protected against challenge infection with wild type virus. Furthers studies in the target specie will be necessary to check the imunogenic and pathogenic properties of the recombinant virus aming use it as a differential attenuated vaccine for cattle.

Key words: BHV-1, BHV-5, recombinant vaccine, rabbit, cattle.

**Master’s Thesis \#386 (Field: Virologia). 98 p. Postgraduate Program inVeterinary Sciences, Faculdade de Veterinária, Universidade Federal do Rio Grande do Sul (UFRGS), Porto Alegre/Brazil. CORRESPONDENCE: A.D. Silva [alemedvet@yahoo.com.br]. 